\title{
Author Correction: Developing a molecular picture of soil organic matter-mineral interactions by quantifying organo-mineral binding
}

\author{
C.J. Newcomb¹, N.P. Qafoku¹, J.W. Grate1, V.L. Bailey \& J.J. De Yoreo,2
}

Nature Communications 8:396 doi:10.1038/s41467-017-00407-9; Article published online: 30 August 2017

In the original version of this Article, the Acknowledgements section omitted the Department of Energy-funded Environmental and Molecular Sciences Laboratory in which the XRD measurements were performed. This error has now been corrected in both the PDF and HTML versions of the Article.

Published online: 05 December 2017

\begin{abstract}
(c) Open Access This article is licensed under a Creative Commons Attribution 4.0 International License, which permits use, sharing, adaptation, distribution and reproduction in any medium or format, as long as you give appropriate credit to the original author(s) and the source, provide a link to the Creative Commons license, and indicate if changes were made. The images or other third party material in this article are included in the article's Creative Commons license, unless indicated otherwise in a credit line to the material. If material is not included in the article's Creative Commons license and your intended use is not permitted by statutory regulation or exceeds the permitted use, you will need to obtain permission directly from the copyright holder. To view a copy of this license, visit http://creativecommons.org/licenses/by/4.0/.
\end{abstract}

(c) The Author(s) 2017

\footnotetext{
${ }^{1}$ Pacific Northwest National Laboratory, 902 Battelle Blvd, Richland, WA 99354, USA. 2 Department of Materials Science and Engineering, University of Washington, 302 Roberts Hall, Seattle, WA 98195, USA. Correspondence and requests for materials should be addressed to

J.J.D.Y. (email: james.deyoreo@pnnl.gov)
} 